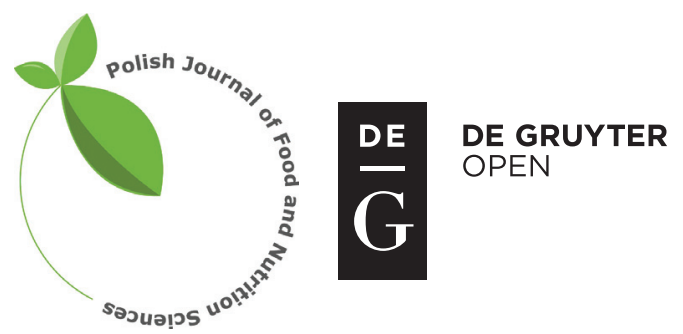

Pol. J. Food Nutr. Sci., 2018, Vol. 68, No. 3, pp. 223-234

DOI: $10.1515 /$ pjfns-2018-0002 http://journal.pan.olsztyn.pl

Original research article

Section: Food Quality and Functionality

\title{
Profiling of the Contents of Amino Acids, Water-Soluble Vitamins, Minerals, Sugars and Organic Acids in Turkish Hazelnut Varieties
}

\author{
Neslihan Göncüoğlu Taş, Vural Gökmen* \\ Food Quality and Safety (FoQuS) Research Group, Department of Food Engineering, Hacettepe University, \\ 06800 Beytepe, Ankara, Turkey
}

Key words: hazelnut, amino acids, vitamins, minerals, sugars, organic acids

Proximate composition, profiles of amino acids, sugars, organic acids, vitamins and minerals of fourteen Turkish hazelnut varieties harvested in 2013 and 2014 were investigated. Glutamic acid, arginine and aspartic acid were the most predominant amino acids, representing of about 50\% of hazelnut protein. Individual amino acid profiles showed significant differences depending upon the harvest year $(p<0.05)$. Concentration of sucrose was the highest followed by fructose, glucose, stachyose, raffinose and myo-inositol, respectively. Phytic acid was predominant organic acid in all varieties, followed by malic acid. Independent of the variety, hazelnuts were rich in pantothenic acid, nicotinic acid, pyridoxal, biotin, thiamine, nicotinamide. Pantothenic and nicotinic acid were significantly higher in most of the varieties in harvest year 2014. Potassium was the most predominant mineral, followed by magnesium, calcium, sodium, manganese, zinc, iron and copper, respectively.

\section{INTRODUCTION}

Hazelnut (Corylus avellana L.) is the commodity that Turkey is foremost in its production contributing 65\% of world hazelnut production with a five-year average value of 590,000 tones [FAO, 2013]. It is cultivated in almost 600,000 hectare area that takes place in the northern part of Turkey and grows mainly between $36^{\circ}-41^{\circ}$ north latitudes, maximum 750-1000 $\mathrm{m}$ altitude and within $30 \mathrm{~km}$ of the coast [Hazelnut Promotion Group, 2012]. There are 18 hazelnut varieties grown in Turkey which are Acı, Cavcava, Çakıldak, Foşa, Ham, İncekara, Kalınkara, Kan, Karafındık, Kargalak, Kuş, Mincane, Palaz, Sivri, Tombul, Uzun Musa, Yassı Badem, and Yuvarlak Badem. They are classified as Giresun or Levant (the varieties that do not grow in Giresun province) according to their quality. The variety Tombul is known as Giresun quality while the other varieties are Levant quality [Alasalvar et al., 2009]. Another classification of hazelnut varieties depends upon their shape and they are divided into three as round, pointed and long [Özdemir \& Devres, 1999].

In addition to its high oil content, hazelnut is also rich in unsaturated fatty acids, oleic acid containing triacylglycerols, and tocopherols which makes hazelnut an important source of healthy lipids. The compositional characteristics of the lipid fraction of various Turkish hazelnuts including the profiles of fatty acids, triacylglycerols, tocopherols and sterols have been previously widely investigated by others [Alasalvar et al.,

\footnotetext{
* Corresponding Author: Tel.: +90 312 2977108; Fax: +90 312 2992123;

E-mail: vgokmen@hacettepe.edu.tr (Prof. Dr. V.l Gökmen)
}

2006, 2009; Köksal et al., 2006; Özdemir \& Devres, 1999]. Recently, the differences in these characteristics of fourteen Turkish hazelnut varieties depending upon the variety and the harvest years have been reported [Tas \& Gökmen, 2015].

The non-lipid part of hazelnuts comprises mainly proteins, carbohydrates, vitamins and minerals. Mineral and vitamin contents of Turkish hazelnuts took the attention of several researchers [Açkurt et al., 1999; Alasalvar et al., 2009; Köksal et al., 2006; Ozdemir \& Akinci, 2004; Özdemir \& Devres, 1999]. Köksal et al. [2006] reported the contents of amino acids, vitamins and minerals for seventeen Turkish hazelnut varieties harvested in 2002. Özdemir \& Devres [1999] also investigated the amino acid profile of Turkish hazelnuts. Alasalvar et al. [2010] reported the content of taste active compounds including sugars, organic acids, condensed tannins and free phenolic acids of eighteen Turkish hazelnut varieties.

There is no study dealing comprehensively with the compositional characteristics of the non-lipid part of hazelnuts taking into account the varietal differences for consecutive harvest years. In this study, fourteen hazelnut varieties grown in the same orchard and harvested in 2013 and 2014 were analyzed for their proximate composition and for the profiles of amino acids, water-soluble vitamins, minerals, sugars and organic acids.

\section{MATERIALS AND METHODS}

\section{Chemicals and consumables}

Hexane ( $\geq 95 \%)$, acetonitrile ( $\geq 99.9 \%)$, methanol $(\geq 99.9 \%)$ and water were purchased from Sigma Aldrich (Steinheim, Germany). Sodium hydroxide, potassium hexacyanoferrate 
(II) trihydrate, zinc sulphate heptahydrate, strontium chloride hexahydrate, boric acid, hydrochloric acid (37\%), nitric acid $(65 \%)$ and sulfuric acid (95-97\%) was supplied from Merck (Darmstadt, Germany). All sugar ( $\geq 99 \%)$, organic acid $(\geq 95 \%)$, amino acid $(\geq 97 \%)$ and vitamin $(\geq 98 \%)$ standards were purchased from Sigma Aldrich (Steinheim, Germany). Standard solutions $(1000 \mu \mathrm{g} / \mathrm{mL})$ of minerals were purchased from Chem-Lab NV (Zedelgem, Belgium).

\section{Hazelnut samples}

The samples of fourteen hazelnut varieties (Ac1, Çakıldak, Foşa, İncekara, Kalınkara, Kan, Kargalak, Kuş, Palaz, Sivri, Tombul, Uzun Musa, Yassı Badem, Yuvarlak Badem), which were grown in the collection orchard of Giresun Hazelnut Research Institute located at the northern east coast of Turkey, were included in the study. The latitude of the collection orchard is $40^{\circ} 54^{\prime} 32.26^{\prime \prime} \mathrm{N}$ and the longitude is $38^{\circ} 21^{\prime}$ 0.73 " E. In the collection orchard, randomly selected hazelnuts were collected by hand at the first week of August when their green leafy covers were turned to pale and the moisture content was decreased to $30 \%$. Then, hazelnuts were sun-dried for 3-5 days until their moisture content was $6 \%$. After removal of green leafy covers, each hazelnut variety with its brown hard shell was packed in three separate bags, each of them containing $2 \mathrm{~kg}$ hazelnuts, and immediately sent for analysis at the harvest years of 2013 and 2014. Until the analysis, hazelnut samples were stored at $-18^{\circ} \mathrm{C}$. Before analysis, hazelnut hard shells were cracked and hazelnut skins were scraped manually. Then, a 100 g portion of hazelnut from each bag was finely grounded with a coffee mill. Three independent samples were analyzed from each hazelnut variety and all analytical measurements were performed in duplicate $(n=6)$.

\section{Determination of proximate composition}

Proximate composition of hazelnut varieties was determined according to methods of Association of Official Analytical Chemists [AOAC, 1990]. Hazelnut samples were dried at $105^{\circ} \mathrm{C}$ in an oven to a constant weight in order to determine moisture contents (AOAC 925.10). Total oil content was determined gravimetrically after Soxhelet extraction with hexane for $10 \mathrm{~h}$ (AOAC 948.22). Kjeldahl method was used to find out total nitrogen content, and protein content was calculated from total nitrogen content value by using a conversion factor of 6.25 (AOAC 984.13). Total ash content of hazelnut varieties was determined after ashing with a gradual temperature increase $\left(250^{\circ} \mathrm{C}-650^{\circ} \mathrm{C}\right)$ and obtaining a constant weight (AOAC 923.03). Carbohydrate content of hazelnut varieties was calculated by subtraction of the total percentage of other constituents from $100 \%$.

\section{Defatting of hazelnuts}

After grinding, $5 \mathrm{~g}$ of hazelnut samples was defatted with hexane by using a Soxhelet extractor at $55^{\circ} \mathrm{C}$ for $10 \mathrm{~h}$. The samples were placed in a flow cabined at room temperature to remove the residual hexane completely. They were stored at $-18^{\circ} \mathrm{C}$ until the analyses of amino acids, sugars, organic acids and water-soluble vitamins were performed.

\section{Analysis of amino acids}

Amino acids were analyzed after acid hydrolysis. First, $50 \mathrm{mg}$ of defatted sample was weighed into glass tubes and $5 \mathrm{~mL}$ of $8 \mathrm{~N} \mathrm{HCl}$ was added onto it. After nitrogen gas flushing to the headspace, screw caps were closed tightly. The tubes were kept at $110^{\circ} \mathrm{C}$ for $23 \mathrm{~h}$ until all amino acids in proteins were completely hydrolyzed. Then, $100 \mu \mathrm{L}$ of hydrolysate were transferred to another glass tube and dried under a gentle stream of nitrogen. The final residue was redissolved in $1 \mathrm{~mL}$ of the mixture of acetonitrile:water $(1: 1, \mathrm{v} / \mathrm{v})$ and filtered through a $0.45 \mu \mathrm{m}$ filter into a vial.

Analysis was performed according to the method described by Kocadağlı et al. [2013]. Samples were injected to the Waters Acquity UPLC system (Waters Corp., Milford, MA, USA) equipped with a triple quadrupole detector (TQD) operated in positive electrospray ionization mode. Chromatographic separation was performed on a Waters Atlantis HILIC column (150 x $2.1 \mathrm{~mm}$ id., $3 \mu \mathrm{m}$ ) by using $0.1 \%$ formic acid in water (A) and $0.1 \%$ formic acid in acetonitrile (B) with a flow rate of $0.4 \mathrm{~mL} / \mathrm{min}$. The gradient program started with $15 \% \mathrm{~A}$ and increased linearly to $40 \% \mathrm{~A}$ in $4 \mathrm{~min}$ and continued to flow for 3 more min with $40 \%$ A. Afterwards, the concentration of A was decreased to its initial condition (15\%) within $1 \mathrm{~min}$. The settings of electrospray source were as described: capillary voltage $3.5 \mathrm{kV}$, cone voltage $20 \mathrm{~V}$, extractor voltage $3 \mathrm{~V}$, source temperature $120^{\circ} \mathrm{C}$, dissolution temperature $350^{\circ} \mathrm{C}$, and dissolution gas (nitrogen) flow $900 \mathrm{~L} / \mathrm{h}$. Amino acids were quantified and qualified in the Multiple Reaction Monitoring (MRM) mode according to the parameters which were given by Kocadağlı et al. [2013].

\section{Analysis of sugars and organic acids}

Analyses of sugars and organic acids were performed as described previously with some modifications [Alasalvar et al., 2012]. A quantity of $0.3 \mathrm{~g}$ of defatted sample was extracted with deionized water in triple stages $(5 \mathrm{~mL}, 2.5 \mathrm{~mL}, 2.5 \mathrm{~mL})$. Extracts were combined in a test tube and centrifuged at $7500 \times g$ for $3 \mathrm{~min}$. Then, $1 \mathrm{~mL}$ of the supernatant was transferred to a test tube and $50 \mu \mathrm{L}$ of Carrez I and Carrez II were added into it. The tubes were vortexed for $2 \mathrm{~min}$ and centrifuged at $7500 \times g$ for $3 \mathrm{~min}$. Afterwards, $1 \mathrm{~mL}$ of the extract was passed through preconditioned Waters Oasis HLB cartridges. Preconditioning was performed by $1 \mathrm{~mL}$ methanol and $1 \mathrm{~mL}$ water, respectively. After discarding the first 8 drops, the rest of the extract was collected into a vial.

Samples were injected to the Agilent 1100 HPLC system (Agilent Technologies, Waldbronn, Germany) containing a quaternary pump, temperature-controlled oven, refractive index detector (RID), and diode array detector (DAD). Chromatographic separation was carried out on a Shodex SH-1011 column $(300 \times 8 \mathrm{~mm}$ id., $7 \mu \mathrm{m})$ by using $0.01 \mathrm{~N}$ $\mathrm{H}_{2} \mathrm{SO}_{4}$ in water with a flow rate of $1 \mathrm{~mL} / \mathrm{min}$. The column temperature was $50^{\circ} \mathrm{C}$. The injection volume was $5 \mu \mathrm{L}$ and the total analysis time was $12 \mathrm{~min}$. Sugar analyses were performed by using RID, and organic acid analysis was performed by using DAD at $210 \mathrm{~nm}$.

\section{Analysis of water-soluble vitamins}

A quantity of $0.3 \mathrm{~g}$ of defatted hazelnut was extracted with deionized water in triple stages $(5 \mathrm{~mL}, 2.5 \mathrm{~mL}, 2.5 \mathrm{~mL})$. Ex- 


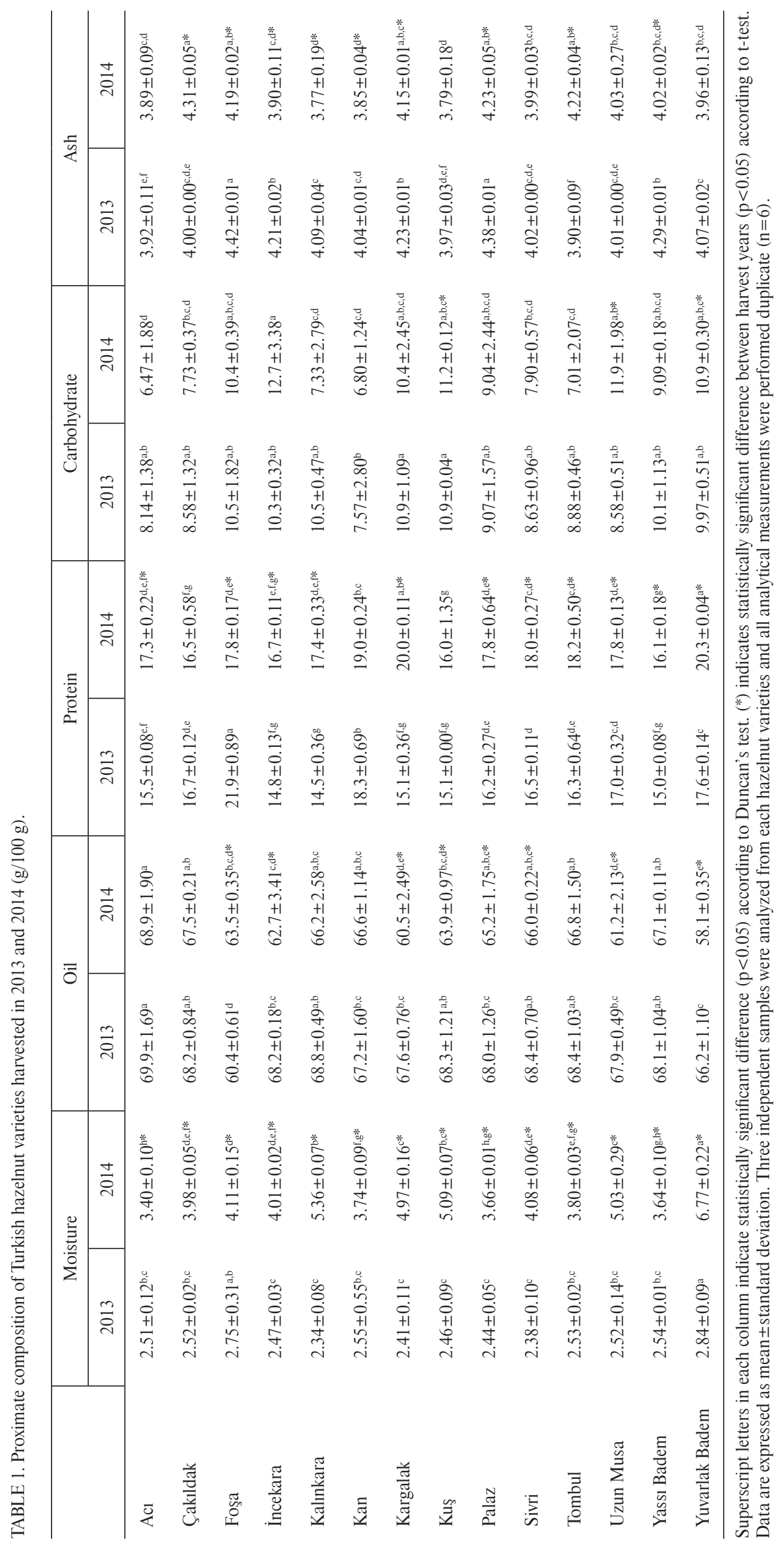




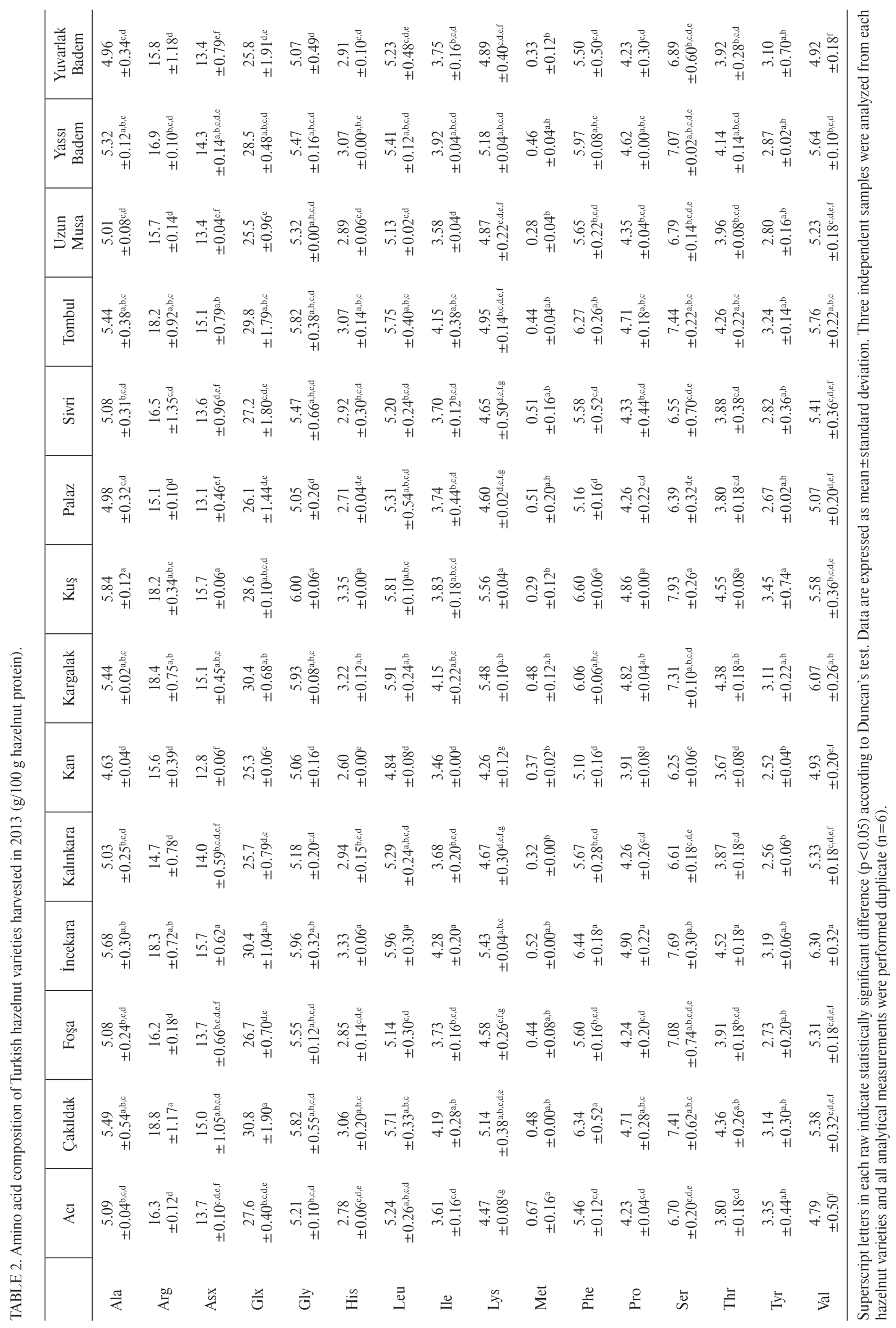




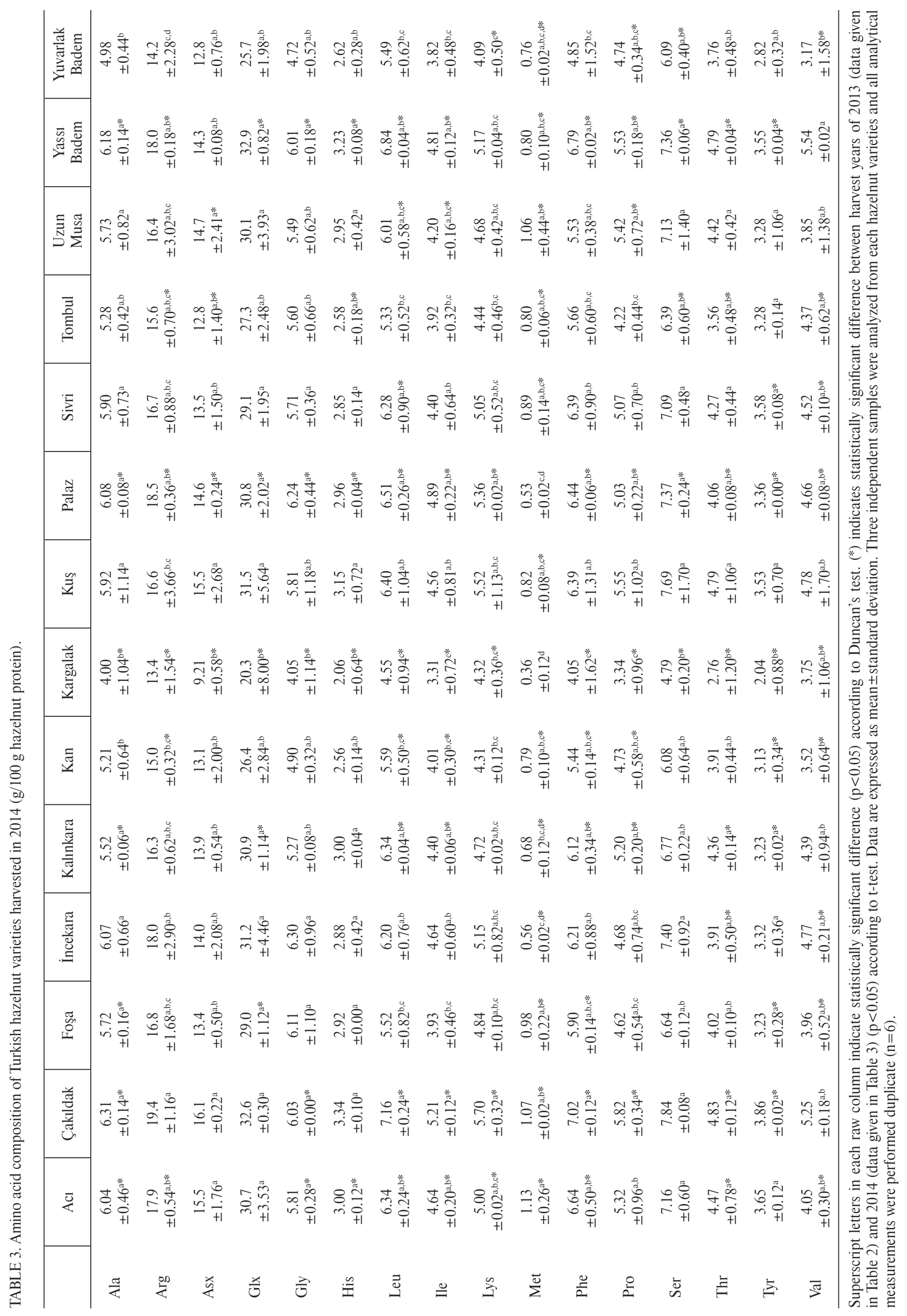


tracts were combined in a test tube and centrifuged at $7500 \times g$ for $3 \mathrm{~min}$. The supernatants were diluted four folds with acetonitrile and water to maintain a final acetonitrile to water ratio of $1: 1(\mathrm{v} / \mathrm{v})$. After centrifugation at $7500 \times \mathrm{g}$ for $3 \mathrm{~min}$, the supernatants were filtered through $0.45 \mu \mathrm{m}$ filter into a vial.

Analysis was performed according to the method described by Y1lmaz \& Gökmen [2013]. Samples were injected to the Waters Acquity UPLC system (Waters Corporation, Milford, MA, USA) combined with a triple quadrupole detector (TQD) operated in positive electrospray ionization mode for all vitamins except for ascorbic acid analyzed at negative ionization mode. Chromatographic separation was performed on a Waters Acquity UPLC BEH C18 column $(100 \times 2.1 \mathrm{~mm}$ id., $1.7 \mu \mathrm{m}$ ) by using combination of $0.1 \%$ formic acid in water (A) and $0.1 \%$ formic acid in methanol (B) with a flow rate of $0.3 \mathrm{~mL} / \mathrm{min}$. The gradient program was as follows: $0-3 \mathrm{~min}$, 99\% A; 3-5 min, 99\% A; 5-5.1 min, 25\% A; 5.1-8 min, 99\% A. The column temperature was $40^{\circ} \mathrm{C}$ and injection volume was $5 \mu \mathrm{L}$. The settings of electrospray source were as described: capillary voltage $1 \mathrm{kV}$, cone gas (nitrogen) flow $10 \mathrm{~L} / \mathrm{h}$, source temperature $120^{\circ} \mathrm{C}$, dissolution temperature $450^{\circ} \mathrm{C}$ and dissolution gas (nitrogen) flow $800 \mathrm{~L} / \mathrm{h}$. Vitamins were identified and quantified in Multiple Reaction Monitoring (MRM) mode by using the $\mathrm{m} / \mathrm{z}$ of $245.1>227.1$ for biotin, $123.1>80.0$ for nicotinamide, $124.0>80.0$ for nicotinic acid, 220.2>90.0 for pantothenic acid, 168.0>150.0 for pyridoxal, and $265.1>122.0$ for thiamine, for pyridoxamine $169.0>152.0,170.1>152.1$ for pyridoxine, 442.0 $>295.0$ for folic acid, 377.0>243.0 for riboflavin, 678.5>147.1 for cyanocobalamine, and 175.1>115.0 for ascorbic acid.

\section{Analysis of minerals}

Analysis of sodium and potassium minerals were performed by using flame emission spectroscopy according to AOAC method 956.01 and calcium, magnesium, manganese, copper, zinc, iron were analyzed by using atomic absorption spectroscopy according to AOAC method 975.03 [AOAC, 1990].

A quantity of $1 \mathrm{~g}$ of ash, obtained after gradual incineration, was dissolved in $5 \mathrm{~mL}$ nitric acid and filtered through an ashless filter paper into a volumetric flask. Then, $10 \mathrm{~mL}$ of a $10 \%$ strontium chloride solution was added onto it and the final volume was completed to $100 \mathrm{~mL}$ with deionized water. Standards of sodium, potassium, calcium, magnesium, manganese, copper, zinc, and iron were prepared with deionized water containing $5 \%$ of nitric acid in different concentrations. Mineral content of both hazelnut samples and standards were analyzed with flame atomic absorption spectrometer (Thermo ICE 3000 Series, Waltham, MA, USA) by using the appropriate lamp and adjusting the wavelength to $766.5 \mathrm{~nm}$ for potassium, $248.3 \mathrm{~nm}$ for iron, $422.7 \mathrm{~nm}$ for calcium, $589.0 \mathrm{~nm}$ for sodium, 285.2 for magnesium, $279.5 \mathrm{~nm}$ for manganese, $324.8 \mathrm{~nm}$ for copper, and $213.9 \mathrm{~nm}$ for zinc.

\section{Statistical analysis}

Experimental data was expressed as mean \pm standard deviation. Significance of differences between varieties was analyzed by using one-way ANOVA Duncan's test $(\mathrm{p}<0.05)$ with SPSS Version 17.0. Differences between harvest years were determined by t-test using Excel $(\mathrm{p}<0.05)$.

\section{RESULTS AND DISCUSSION}

\section{Proximate composition}

Proximate compositions of hazelnut varieties harvested in the year of 2013 and 2014 are given in Table 1. Oil constituted the largest part of the hazelnuts, followed by proteins, carbohydrates and ash. Foşa $(60.4 \mathrm{~g} / 100 \mathrm{~g})$ and Yuvarlak Badem $(58.1 \mathrm{~g} / 100 \mathrm{~g})$ had the lowest oil contents in harvest years of 2013 and 2014, respectively. Ac1 was found to contain the highest amount of oil in both harvest years $(69.9 \mathrm{~g} / 100 \mathrm{~g}$ in 2013 and $68.9 \mathrm{~g} / 100 \mathrm{~g}$ in 2014). Total oil content of hazelnut varieties did not change significantly $(\mathrm{p}>0.05)$ depending upon the harvest years except for the varieties Foşa, Incekara, Kargalak, Kuş, Palaz, Sivri, Uzun Musa, and Yuvarlak Badem. Köksal et al. [2006] determined the total oil contents of seventeen Turkish hazelnut varieties harvested in 2002 and the values ranged between $56.07 \mathrm{~g} / 100 \mathrm{~g}$ and $68.52 \mathrm{~g} / 100 \mathrm{~g}$. They also reported that Cavcava variety had the lowest oil content while Kalınkara had the highest. Kiralan et al. [2015] found the total oil contents of Turkish hazelnut varieties harvested in the years of 2009-2010 ranged from 55.01 to $63.26 \mathrm{~g} / 100 \mathrm{~g}$ that were relatively lower compared to the total oil contents found in this study. Oil contents of nineteen Portuguese hazelnut cultivars were reported to range from 59.3 to $69.0 \mathrm{~g} / 100 \mathrm{~g}$ [Amaral et al., 2006], which were almost in the same range with Turkish hazelnut varieties harvested in 2013 and 2014. Moreover, total oil contents of Spanish hazelnut cultivars, ranging from 57.22 to $64.1 \mathrm{~g} / 100 \mathrm{~g}$, were lower than the total oil contents of Turkish hazelnut varieties in this study [Parcerisa et al., 1995].

Protein contents of hazelnuts were 14.5-21.9 g/100 g and $16.0-20.3 \mathrm{~g} / 100 \mathrm{~g}$ in the harvest years of 2013 and 2014, respectively. Kalınkara and Kuş were the varieties that had the lowest protein content while Foşa and Yuvarlak Badem had the highest in the harvest years 2013 and 2014, respectively. Protein content of Çakıldak, Kan, and Kuş varieties did not change significantly ( $p>0.05$ ) between harvest years, 2013 and 2014. The protein content of Kalınkara harvested in 2002 was also found to be the lowest with $11.7 \mathrm{~g} / 100 \mathrm{~g}$ and the protein content was the highest in Yuvarlak Badem and Cavcava with $20.8 \mathrm{~g} / 100 \mathrm{~g}$ but they were lower than the protein content found in this study [Köksal et al., 2006]. Compared to the protein contents of Turkish hazelnut varieties, Portuguese hazelnut varieties were reported to have lower protein contents ranging from 9.3 to $12.7 \mathrm{~g} / 100 \mathrm{~g}$ [Amaral et al., 2006]. Carbohydrate contents were 7.57-10.9 g/100 g in 2013 and $6.47-12.7 \mathrm{~g} / 100 \mathrm{~g}$ in 2014. Ash contents ranged between $3.90 \mathrm{~g} / 100 \mathrm{~g}$ (Tombul) and $4.42 \mathrm{~g} / 100 \mathrm{~g}$ (Foşa) in 2013, and between $3.77 \mathrm{~g} / 100 \mathrm{~g}$ (Kalınkara) and $4.31 \mathrm{~g} / 100 \mathrm{~g}$ (Çakıldak) in 2014. Significant differences $(p<0.05)$ were also observed in the ash contents between harvest years except for the varieties Acı, Sivri, Kuş, Uzun Musa, and Yuvarlak Badem.

\section{Amino acid profile}

Amino acid compositions of Turkish hazelnut varieties harvested in 2013 and 2014 are given in Table 2 and Table 3, respectively. Glx (glutamine plus glutamic acid), Arg, and Asx (asparagine plus aspartic acid) were found to be the most 
dominant amino acids in Turkish hazelnuts. These three amino acids constituted about $50 \%$ of the total amino acids. Venkatachalam \& Sathe [2006] also found these three amino acids as the most abundant amino acids in hazelnuts. Ruggeri et al. [1998] reported that glutamic acid, arginine and aspartic acid accounted for about $40 \%$ of protein of Italian hazelnuts, which was lower than found in this study. Individual contribution of the other amino acids did not exceed $8 \mathrm{~g} / 100 \mathrm{~g}$ of hazelnut protein. Moreover, hazelnuts were found to contain all essential amino acids (Arg, His, Ile, Leu, Lys, Met, Phe, Thr, Val) except Trp. Their total concentrations were 44.8-55.0 g/100 g protein and 38.6-59.0 g/100 g protein in 2013 and 2014, respectively. It should be noted here that Trp was degraded during acid hydrolysis conditions. Alasalvar et al. [2003] reported Trp as the least abundant amino acid in Tombul variety. Among the essential amino acids, Arg was found to be the highest $(>13.4 \mathrm{~g} / 100 \mathrm{~g})$ and Met was the lowest $(<1.13 \mathrm{~g} / 100 \mathrm{~g})$. The second dominant essential amino acid was either Phe or Leu depending upon the variety of hazelnuts.

Significant differences were found between the concentrations of individual amino acids in both harvest years $(\mathrm{p}<0.05)$. Compared to 2013, the most remarkable change was observed in Kargalak, Palaz and Yassı Badem with significant increases in the concentrations of almost all amino acids $(p<0.05)$. Met concentrations showed significant change in almost all hazelnut varieties $(\mathrm{p}<0.05)$. The concentrations of Asx, Glx, Gly, Lys and Ser did not change significantly in most of the hazelnut varieties depending upon the harvest year $(\mathrm{p}>0.05)$.

\section{Profiles of sugars and organic acids}

Hazelnuts were found to contain a range of saccharides including fructose, glucose, sucrose, raffinose, stachyose, and a polyol myo-inositol. Sugar contents of Turkish hazelnut varieties harvested in 2013 and 2014 are given in Table 4, respectively. Independently of the harvest year, sugar amounts in different hazelnut varieties were in the following order: sucrose $>$ fructose $>$ glucose $>$ stachyose $>$ raffinose $>$ myo-inositol with minor exceptions. Sucrose content showed large variations, being the highest in Kalınkara (6.45 g/100 g) and the lowest in Kan $(1.81 \mathrm{~g} / 100 \mathrm{~g})$ in 2013. Similar patterns were observed for other sugars in these two varieties. For example, stachyose $(0.41 \mathrm{~g} / 100 \mathrm{~g})$, raffinose $(0.21 \mathrm{~g} / 100 \mathrm{~g})$ and myo-inositol $(0.15 \mathrm{~g} / 100 \mathrm{~g})$ were found in the highest amounts in Kalınkara. However, Kan contained the lowest amounts of stachyose $(0.13 \mathrm{~g} / 100 \mathrm{~g})$, raffinose $(0.07 \mathrm{~g} / 100 \mathrm{~g})$ and myo-inositol ( $0.03 \mathrm{~g} / 100 \mathrm{~g})$. Yuvarlak Badem contained the highest amount of sucrose $(3.22 \mathrm{~g} / 100 \mathrm{~g})$ while Çakıldak had the lowest amount (1.13 g/100 g) in 2014. In 2014, the highest amounts of glucose $(1.01 \mathrm{~g} / 100 \mathrm{~g})$ and fructose $(1.08 \mathrm{~g} / 100 \mathrm{~g})$ were found in Çakıldak. Foşa, Incekara, and Yuvarlak Badem were varieties that showed significant differences in the contents of all sugars between harvest years of 2013 and $2014(\mathrm{p}<0.05)$.

Cerbulis [1955] reported sucrose, glucose, fructose, stachyose, raffinose, and myo-inositol as the major sugars in Turkish hazelnuts. Alasalvar et al. [2003] quantified these sugars in Turkish Tombul hazelnut. They reported sucrose $(2.67 \mathrm{~g} / 100 \mathrm{~g})$ as the most abundant sugar, followed by stachyose $(0.48 \mathrm{~g} / 100 \mathrm{~g})$, raffinose and fructose (both $0.14 \mathrm{~g} / 100 \mathrm{~g})$, glucose $(0.11 \mathrm{~g} / 100 \mathrm{~g})$, and myo-inositol $(0.04 \mathrm{~g} / 100 \mathrm{~g})$. Alasalvar et al. [2010] reported total sugar content of eighteen Turkish hazelnut varieties between 1.99 (Kan) and $4.94 \mathrm{~g} / 100 \mathrm{~g}$ (Uzun Musa). They also found that sucrose was responsible for $80-90 \%$ and that stachyose constituted $5-13 \%$ of all the sugars while the other sugars were in low amounts. Cristofori et al. [2008] found the same sugars except myo-inositol in 24 hazelnut varieties originated mostly from Italy and collected from other countries. According to average values of their three harvest year results sucrose ranged from $3.98 \mathrm{~g} / 100 \mathrm{~g}$ in Tonda Rossa to $5.95 \mathrm{~g} / 100 \mathrm{~g}$ in Tonda Gentile Romana and constituted $80 \%$ of the sugars. Moreover, stachyose represented the 5-10\% of the total sugars, followed by raffinose, glucose, and fructose.

Turkish hazelnuts were found to contain phytic and malic acids in both harvest years (Table 4). On contrary to the previous studies [Alasalvar et al., 2003, 2010; Cristofori et al., 2008], phytic acid was found as the predominant organic acid in hazelnuts in the present study. Its content ranged between $0.64 \mathrm{~g} / 100 \mathrm{~g}$ (Foşa) and $1.63 \mathrm{~g} / 100 \mathrm{~g}$ (Yuvarlak Badem) in harvest year 2013, and between $0.36 \mathrm{~g} / 100 \mathrm{~g}$ (Yuvarlak Badem) and $0.71 \mathrm{~g} / 100 \mathrm{~g}$ (Kargalak) in harvest year 2014. Yassı Badem was found to contain the lowest amount of malic acid ( 0.14 and $0.18 \mathrm{~g} / 100 \mathrm{~g}$, respectively) in both harvest years while Kalınkara had the highest with $0.90 \mathrm{~g} / 100 \mathrm{~g}$ in 2013 and $0.86 \mathrm{~g} / 100 \mathrm{~g}$ in 2014.

\section{Water-soluble vitamins}

Hazelnut varieties were found to be high in pantothenic acid and nicotinic acid (Table 5). They were also found to contain pyridoxal, biotin, thiamine and nicotinamide, but in relatively small quantities. Their amounts in different hazelnut varieties were in the following order: pantothenic acid $>$ nicotinic acid $>$ pyridoxal $>$ biotin $>$ thiamine $>$ nicotinamide. Pantothenic acid was the lowest in Kan $(0.83 \mathrm{mg} / 100 \mathrm{~g})$ and the highest in Çakıldak $(1.60 \mathrm{mg} / 100 \mathrm{~g})$ in harvest year 2013. Nicotinic acid was not detected in Yuvarlak Badem while the highest in Kargalak (0.79 mg/100 g). Alasalvar et al. [2003] reported pantothenic acid content of Turkish Tombul as $1.12 \mathrm{mg} / 100 \mathrm{~g}$ which is in accordance with the results obtained in this study. The amounts of pantothenic acid and nicotinic acid were found to be significantly higher in most of the varieties in harvest year $2014(\mathrm{p}<0.05)$. Pantothenic acid content ranged from $0.81 \mathrm{mg} / 100 \mathrm{~g}$ (Kan) to $2.63 \mathrm{mg} / 100 \mathrm{~g}$ (Yassı Badem) and nicotinic acid was not detected in Kan while its highest content reaching $1.73 \mathrm{mg} / 100 \mathrm{~g}$ was in Kalınkara in harvest year 2014. On contrary to this study, niacin was reported as the most predominant vitamin in hazelnuts followed by vita$\min \mathrm{B}_{1}, \mathrm{~B}_{2}, \mathrm{~B}_{6}$ [Açkurt et al., 1999; Köksal et al., 2006]. Folic acid and ascorbic acid were also found in hazelnuts in small quantities [Alasalvar et al., 2003; Köksal et al., 2006]. The reason for the lack of ascorbic acid in Turkish hazelnut varieties harvested in 2013 and 2014 might be related with its oxidation as an antioxidant, and with the presence of $\mathrm{Fe}^{3+}$ or $\mathrm{Cu}^{2+}$ which might cause its degradation [Belitz et al., 2009]. Folic acid could also lose its activity depending on the harvesting or storage conditions [Scott, 1999]. 


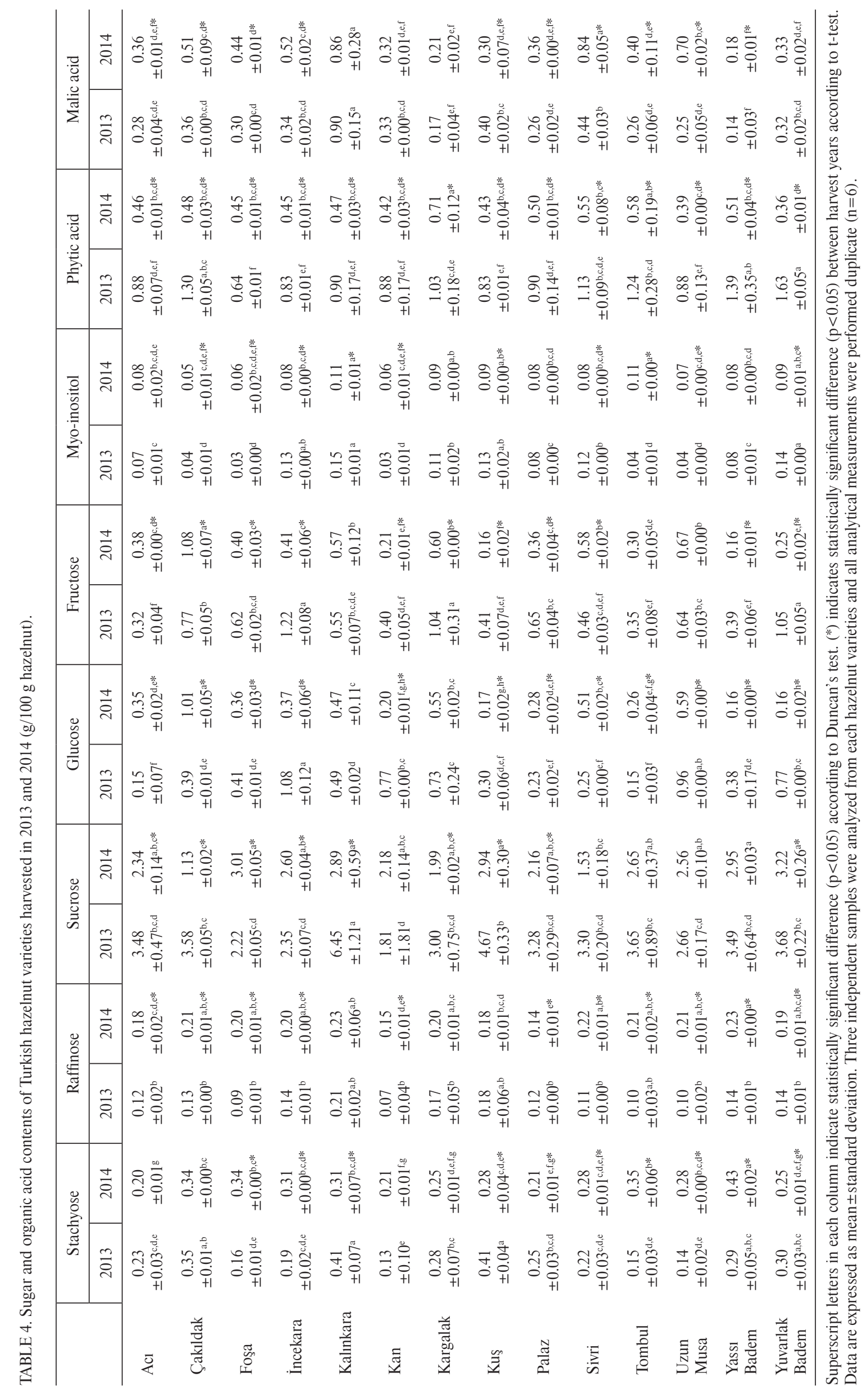




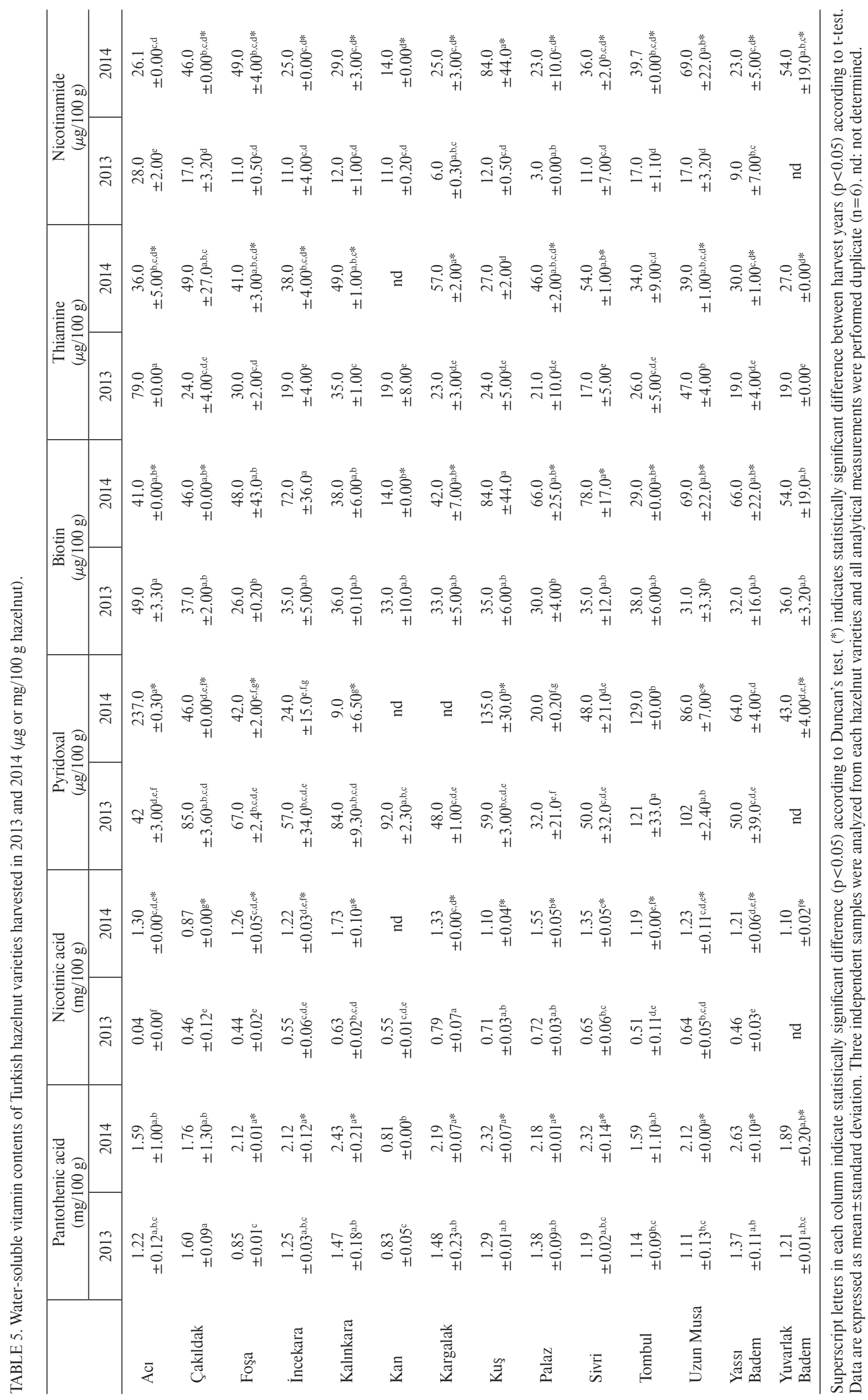




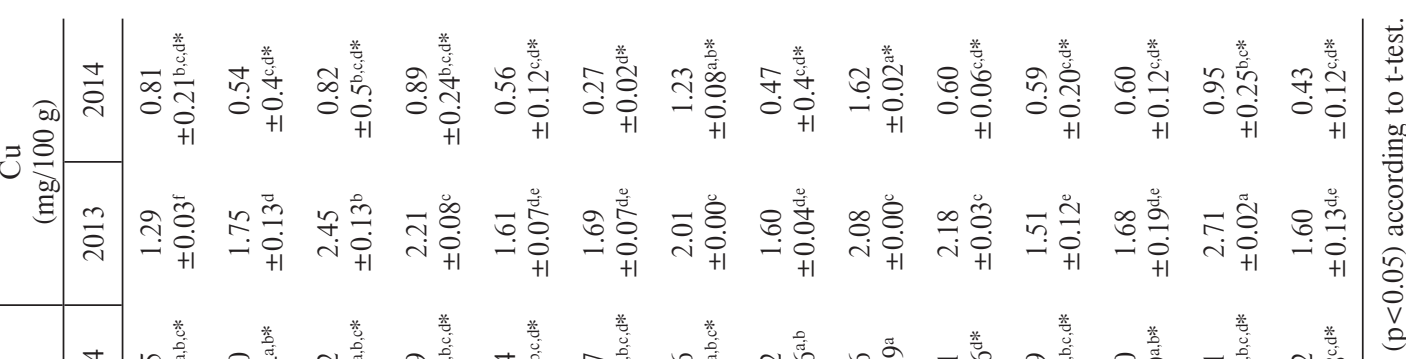

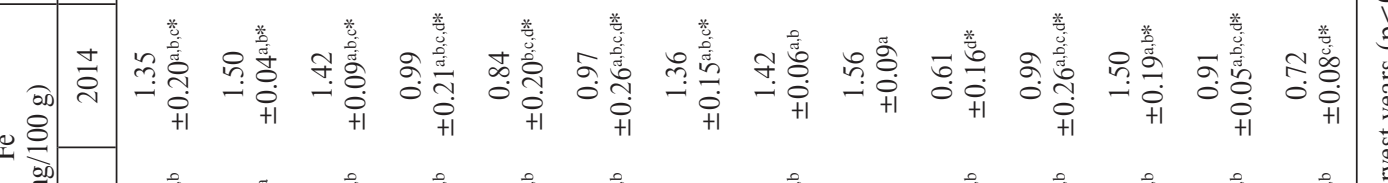

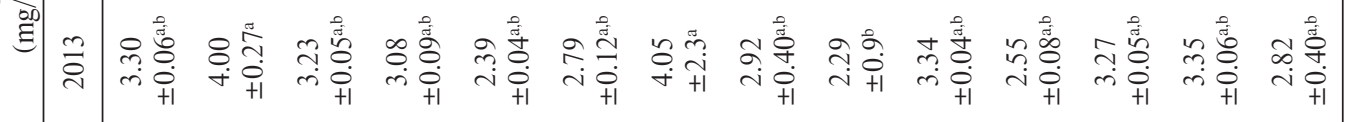

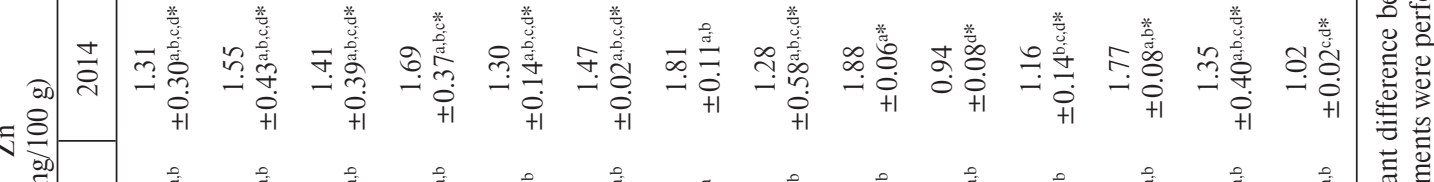

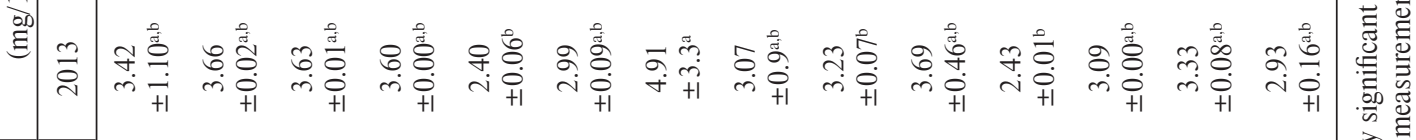

=

气

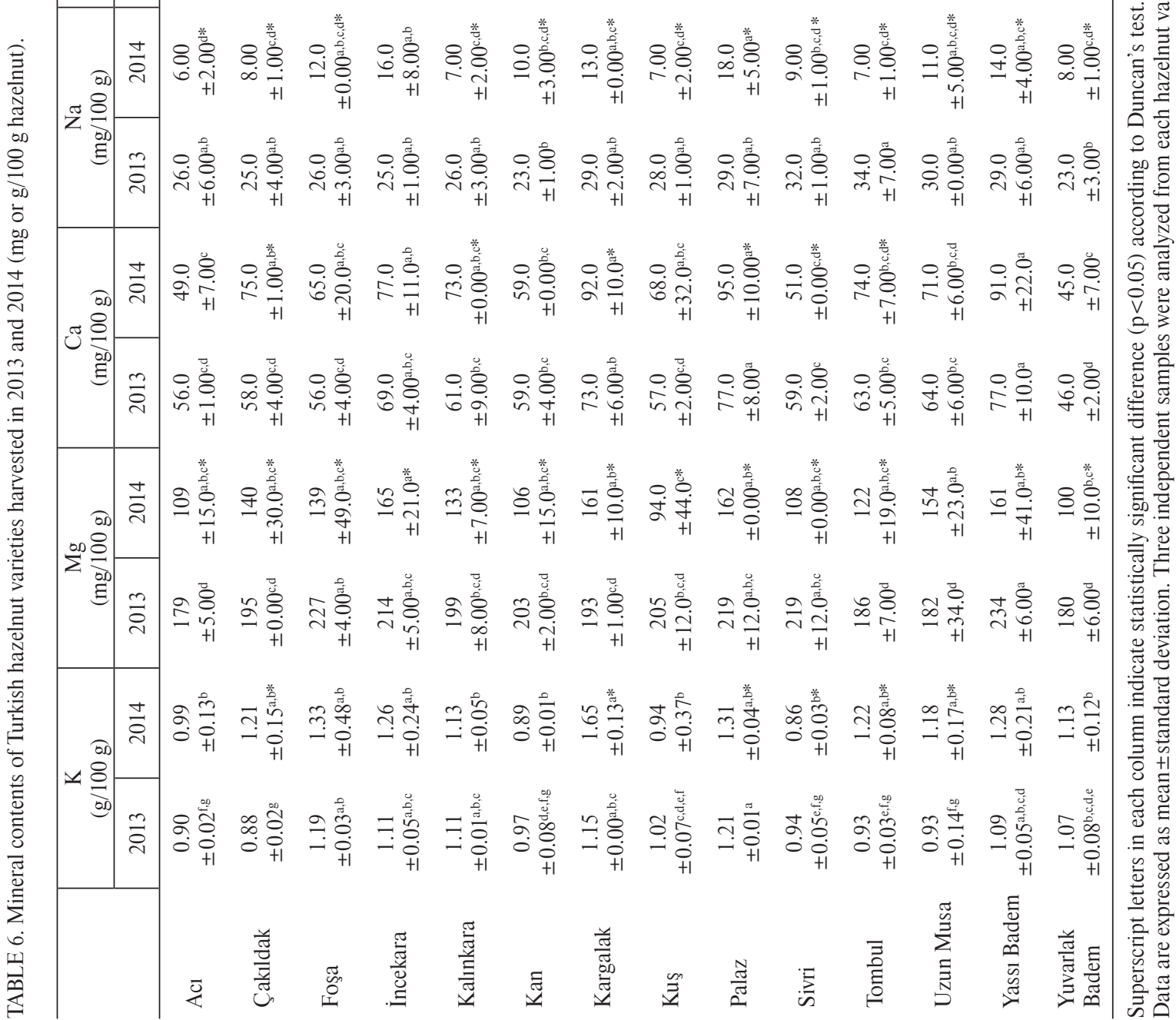




\section{Mineral profile}

Mineral contents of Turkish hazelnut varieties are given in Table 6. Among the minerals, potassium was the most predominant, followed by magnesium, calcium, sodium, manganese, zinc, iron, and copper. The content of potassium ranged from $0.88 \mathrm{~g} / 100 \mathrm{~g}$ (Çakıldak) to $1.21 \mathrm{~g} / 100 \mathrm{~g}$ (Palaz) in 2013, while it was between $0.86 \mathrm{~g} / 100 \mathrm{~g}$ (Sivri) and $1.65 \mathrm{~g} / 100 \mathrm{~g}$ (Kargalak) in 2014. Açkurt et al. [1999] also reported potassium as the most abundant mineral in Turkish hazelnuts with a mean content of $0.64 \mathrm{~g} / 100 \mathrm{~g}$. They also reported magnesium as the second highest mineral followed by calcium, and copper as the least mineral in parallel with the findings of the present study. On contrary, potassium was found to be the second abundant mineral followed by phosphorous, calcium, and magnesium by other researchers [Alasalvar et al., 2009; Ozdemir \& Akinci, 2004]. There were significant changes in the contents of mineral elements of Çakıldak, Kalınkara, Kargalak, Palaz, Sivri, and Tombul between the harvest years $(p<0.05)$. These changes have been attributed to the harvest year, climate, composition of soil and watering [Açkurt et al., 1999, 2009; Köksal et al., 2006].

\section{CONCLUSIONS}

In conclusion, proximate composition and particularly the characteristics of the non-lipid fraction of fourteen hazelnut varieties were comprehensively evaluated for two consecutive harvest years. The data reported here provides in depth information on the contents of amino acids, water-soluble vitamins, mineral elements, sugars and organic acids in hazelnut varieties grown in Turkey. This kind of information would be helpful to estimate the nutritional potential of hazelnuts as influenced by varietal and seasonal changes.

\section{ACKNOWLEDGEMENTS}

Authors are grateful to Giresun Hazelnut Research Institute for providing hazelnut samples.

\section{RESEARCH FUNDING}

This study was supported by The Scientific and Technological Research Council of Turkey (TUBITAK) within 'Intensified Cooperation (IntenC): Promotion of German-Turkish Higher Education Research' program (Project no 1130178).

\section{CONFLICT OF INTERESTS}

Authors declare no conflict of interests.

\section{REFERENCES}

1. Açkurt F., Özdemir M., Biringen G., Löker M., Effect of geographical origin and variety on vitamin and mineral composition of hazelnut (Corylus avellana L.) varieties cultivated in Turkey. Food Chem., 1999, 65, 309-313.

2. Alasalvar C., Shahidi F., Liyanapathirana C.M., Ohshima T., Turkish Tombul hazelnut (Corylus avellana L.). 1. Compositional characteristics. J. Agric. Food Chem., 2003, 51, 3790-3796.
3. Alasalvar C., Amaral J.S., Shahidi F., Functional lipid characteristics of Turkish Tombul hazelnut (Corylus avellana L.). J. Agric. Food Chem., 2006, 54, 10177-10183.

4. Alasalvar C., Amaral J.S., Satır G., Shahidi F., Lipid characteristics and essential minerals of native Turkish hazelnut varieties (Corylus avellana L.). Food Chem., 2009, 113, 919-925.

5. Alasalvar C., Pelvan E., Amarowicz R., Effect of roasting on taste-active compounds of Turkish hazelnut varieties (Corylus avellana L.). J. Agric. Food Chem., 2010, 58, 8674-8679.

6. Alasalvar C., Topal B., Serpen A., Bahar B., Pelvan E., Gökmen V., Flavor characteristics of seven grades of black tea produced in Turkey. J. Agric. Food Chem., 2012, 60, 6323-6332.

7. Amaral J.S., Casal S., Citova I., Santos A., Seabra R.M., Oliveira B.P.P., Characterization of several hazelnut (Corylus avellana L.) cultivars based in chemical, fatty acid and sterol composition. Eur. Food Res. Technol., 2006, 222, 274-280.

8. AOAC. 1990, Official Methods of Analysis of the Association of Official Analytical Chemists, Washington.

9. Belitz H.D., Grosch W., Schieberle P., Vitamins. 2009, in: Food Chemistry, $4^{\text {th }}$ rev. and extended ed., Springer, Berlin, pp. 403-420 .

10. Cerbulis J., Carbohydrates in hazel (Corylus'sp.). I. Major sugar component in Turkish hazelnut kernel. J. Am. Chem. Soc., 1955, 77, 6054-6056.

11. Cristofori V., Ferramondo S., Bertazza G., Bignami C., Nut and kernel traits and chemical composition of hazelnut (Corylus avellana L.) cultivars. J. Sci. Food Agric., 2008, 88, 1091-1098.

12. Food and Agriculture Organization of the United Nations (FAO). 2013, FAO statistics division. [http://faostat3.fao.org/ download/Q/QC/E]. Accessed 13 June 2017.

13. Hazelnut Promotion Group. 2012, Turkey's hazelnut. [http:// www.ftg.org.tr/en/ turkish-hazelnut-turkeys-hazelnut.html]. Accessed 13 June 2017.

14. Kıralan S., Yorulmaz A., Şimşek A., Tekin A., Classification of Turkish hazelnut oils based on their triacylglycerol structures by chemometric analysis. Eur. Food Res. Technol., 2015, 240, 679-688.

15. Kocadağı T., Özdemir K.S., Gökmen V., Effects of infusion conditions and decaffeination on free amino acid profiles of green and black tea. Food Res. Int., 2013, 53, 720-725.

16. Köksal A.I., Artik N., Şimşek A., Güneş N., Nutrient composition of hazelnut (Corylus avellana L.) varieties cultivated in Turkey. Food Chem., 2006, 99, 509-515.

17. Ozdemir F., Akinci I., Physical and nutritional properties of four major commercial Turkish hazelnut varieties. J. Food Eng., 2004, 63, 341-347.

18. Özdemir M., Devres O., Turkish hazelnuts: Properties and effect of microbiological and chemical changes on quality. Food Rev. Int., 1999, 15, 309-333.

19. Parcerisa J., Boatella J., Codony R., Rafecas M., Castellote A.I., Garcia J., Lopez A., Romero A., Comparison of fatty acid and triacylglycerol compositions of different hazelnut varieties (Corylus avellana L.) cultivated in Catalonia (Spain). J. Agric. Food Chem., 1995, 43, 13-16.

20. Ruggeri S., Cappelloni M., Gambelli L., Carnovale E., Chemical composition and nutritive value of nuts grown in Italy. Ital. J. Food Sci., 1998, 10, 243-252.

21. Scott J.M., Folate and vitamin $B_{12}$. Proc. Nutr. Soc., 1999, 58, $441-448$. 
22. Tas N.G., Gökmen V., Profiling triacylglycerols, fatty acids and tocopherols in hazelnut varieties grown in Turkey. J. Food Compost. Anal., 2015, 44, 115-121.

23. Venkatachalam M., Sathe S.K., Chemical composition of selected edible nut seeds. J. Agric. Food Chem., 2006, 54, 4705-4714.
24. Yılmaz C., Gökmen V., Compositional characteristics of sour cherry kernel and its oil as influenced by different extraction and roasting conditions. Ind. Crops Prod., 2013, 49, 130-135.

Submitted: 5 March 2017. Revised: 14 June, 22 June and 8 October 2017. Accepted: 3 November 2017. Published on-line: 7 February 2018. 